\title{
Glucose Metabolism in a Microbial Fuel Cell. Stoichiometry of Product Formation in a Thionine-mediated Proteus vulgaris Fuel Cell and its Relation to Coulombic Yields
}

\author{
By C. F. THURSTON,${ }^{1 *}$ H. P. BENNETTO, ${ }^{2}$ G. M. DELANEY, ${ }^{2}$ \\ J. R. MASON, ${ }^{1}$ S. D. ROLLER ${ }^{1}$ AND J. L. STIRLING ${ }^{3}$ \\ Departments of ${ }^{1}$ Microbiology, ${ }^{2}$ Chemistry and ${ }^{3}$ Biochemistry, Queen Elizabeth College, \\ Campden Hill Road, London W8 7AH, UK
}

(Received 9 October 1984)

\begin{abstract}
The pattern of glucose metabolism was studied in a thionine-mediated Proteus vulgaris fuel cell by using ${ }^{14} \mathrm{C}$-labelled glucose. Added glucose was rapidly taken up by the bacteria and converted to $\mathrm{CO}_{2}$, acetate, lactate and a fourth product, tentatively identified as propionate. When the glucose-dependent electric current from the fuel cells had been completely discharged, about $50 \%$ of glucose carbon was found in $\mathrm{CO}_{2}, 30 \%$ in acetate, $10 \%$ incorporated in the bacteria, and the residual $10 \%$ distributed as small amounts in various soluble products. Thus, although there was transient accumulation of lactate and 'propionate', these were largely reutilized. Coulombic yield from glucose oxidation was about $50 \%$ and correlated with the amount of $\mathrm{CO}_{2}$ produced. Glucose metabolism in the fuel cell was intermediate between conventional aerobic and anaerobic conditions. Under anaerobic (conventional) conditions acetate, lactate and 'propionate' were produced and not reutilized. Under aerobic conditions, acetate and lactate were only transiently produced and the rate of glucose uptake was lower. The major limitation on coulombic yield from glucose oxidation was the production of acetate.
\end{abstract}

\section{INTRODUCTION}

Fuel cells which have biologically catalysed anodic reactions offer the potential for use of a wide range of organic fuels in the generation of electrical power (Aston \& Turner, 1984; Bennetto, 1984). Where a fuel is capable of undergoing only one or a few successive oxidation steps it may be most practicable to use isolated enzymes to catalyse its oxidation in an anodic reaction and this has been demonstrated, for instance, in an enzyme fuel cell which utilizes alcohol dehydrogenase to oxidize methanol (Davis et al., 1983). But if fuels such as carbohydrates are to be used efficiently, whole micro-organisms will probably be more economical fuel cell catalysts as the oxidation process involves a large number of enzyme-catalysed steps.

We have shown previously that a number of micro-organisms can oxidize substrates to provide electric current in the milliampere range using small experimental fuel cells, in which the transfer of electrons from the micro-organisms to an anode is coupled by a soluble redox mediator (Bennetto et al., 1983; Stirling et al., 1983; Delaney et al., 1984). In these experiments the sustained output of current was shown to be dependent upon provision of oxidizable substrate. We estimated coulombic yields of $30-60 \%$ for the complete oxidation of glucose by Proteus vulgaris from measurements of the area under current versus time plots for known amounts of substrate (Delaney et al., 1984). To obtain the number of coulombs derived from added glucose it was necessary to subtract the coulombs (area) delivered by an otherwise identical 'blank' fuel cell which had not been given any exogenous substrate, since the oxidation of endogenous cellular material yielded a significant quantity of coulombs in the absence of added substrate. This differential procedure assumes that oxidation of endogenous substrate(s) is not altered by addition of exogenous substrate and that the behaviour of the two fuel cells is 
precisely the same. P. vulgaris was chosen for detailed study because its endogenous activity was substantially less than that of other micro-organisms we have tested, and it gave the most consistent and reproducible results.

An important question raised is why the coulombic yield did not correspond to that expected from the complete oxidation of glucose added to the fuel cell. One explanation would be that some of the added glucose is not metabolized at all and it is equally possible that glucose is only partially oxidized. Another possibility is that electrons derived from the oxidation of glucose may not be transferred to the electrode with high efficiency. In order to establish the pattern of glucose metabolism under fuel cell conditions, we have used radioactively labelled glucose so that its uptake, and the products formed from it, may be measured. This, in turn, has allowed the coulombic yield of this particular system to be determined with greater certainty.

\section{METHODS}

Organism and conditions of culture. Proteus rulgaris NCTC 10020 was maintained on nutrient agar slopes and grown aerobically on nutrient broth with $10 \mathrm{~mm}$-glucose added. Cultures were harvested by centrifugation after $17 \mathrm{~h}$ growth at $30^{\circ} \mathrm{C}$ in conical flasks on a rotary shaker $(220 \mathrm{r}$.p.m.). Cells were washed three times and resuspended in 0.1 M-potassium phosphate, $\mathrm{pH} 7.0$, and stored at $4{ }^{\circ} \mathrm{C}$ before use. Bacterial suspensions were used for the experiments described on the day following harvesting, thus allowing prior determination of dry weight ( $\mathrm{mg} \mathrm{ml}^{-1}$ ).

Experimental fuel cell. These were made from two perspex half-cells separated by a cation-permeable membrane, sealed in place between two silicone rubber gaskets. Each half-cell had a capacity of $20 \mathrm{ml}(50 \times 57 \times$ $8 \mathrm{~mm}$ ) and was provided with inlets for gas bubbling at the bottom. Outlets at the top allowed for escape of gas and also provided for electrode connection and sampling of anolyte solution. The anode electrodes were reticulated vitreous carbon $(35 \times 50 \times 7 \mathrm{~mm})$ and had a surface area of approximately $800 \mathrm{~cm}^{2}$. The cathode electrodes were $10 \times 40 \mathrm{~mm}$ bright platinum foil. A detailed description of this equipment has been published previously (Delaney et al., 1984).

Fuel cells were maintained in a water bath at $30 \pm 0 \cdot 2^{\circ} \mathrm{C}$. The cathode compartments contained $15 \mathrm{ml} 0.2 \mathrm{M}$ potassium ferricyanide, $0 \cdot 1 \mathrm{M}$-potassium phosphate, $\mathrm{pH} 7 \cdot 0$. The anode compartment contained $30 \mathrm{mg}$ (dry wt) $P$. vulgaris in $0.1 \mathrm{M}$-potassium phosphate, $\mathrm{pH} 7.0$, and $1 \mathrm{~mm}$-thionine (the mediator of electron transfer from organisms to the anode electrode; see Delaney et al., 1984). After filling the cell compartments, pre-wetted oxygenfree nitrogen was initially bubbled through both anode and cathode solutions. Under these conditions endogenous activity of the bacteria reduced the thionine, and an open circuit e.m.f. of about $0.7 \mathrm{~V}$ was established. Before the addition of glucose to the anode compartment, the supply of nitrogen to the cathode compartment was stopped, and its outlets were sealed. One outlet of each anode compartmert was connected to a trap containing $6 \mathrm{ml} 0.833 \mathrm{M}$ sodium hydroxide, and all other outlets were plugged. The flow of nitrogen through the anode compartment and the traps was continued throughout the experiments at $1-5 \mathrm{ml} \mathrm{min}^{-1}$. When the glucose substrate was added (see below) $100 \Omega$ or $560 \Omega$ resistance was immediately connected to make an external circuit for each fuel cell.

Electrical measurements. The e.m.f. for each cell was measured using a multichannel voltmeter (Datastore 7066, Solartron Ltd, Farnborough, UK) and analogue scanner (Minate 7010. Solartron) connected to a microcomputer (380Z, Research Machines Ltd. Oxford, UK). Currents from the cells were calculated as the product of the measured voltages and the reciprocal of the known external resistance. The internal resistance of the fuel cells ( 1.5 $\Omega$ ) was ignored. Coulombic outputs were computed from a graphical integration of the areas under current versus time curves.

Substrate addition and sampling. Glucose $(10 \mathrm{~mm})$ containing $\left[\mathrm{U}-{ }^{1+} \mathrm{C}\right] \mathrm{glucose}(\mathrm{New}$ England Nuclear, crystalline solid) was added to the anode compartment by injection through a vaccine stopper in $10 \mu \mathrm{mol}$ or $25 \mu \mathrm{mol}$ amounts. Specific activity of glucose is given in the legends to Figs 1 and 3.

Accumulation of ${ }^{1+} \mathrm{CO}_{2}$ in the trap was measured by withdrawing $10 \mu 1$ samples for scintillation counting and the total $\mathrm{CO}_{2}$ trapped was determined at the end of each experiment by titration as follows. The contents of the trap were washed into a beaker and diluted to $200 \mathrm{ml}$ with freshly boiled distilled water for immediate titration under nitrogen with $0.01 \mathrm{M} .0 .02 \mathrm{M}$ or $0.05 \mathrm{M}-\mathrm{HCl}$ which was added to the stirred mixture by a high precision pump at $0.5 \mathrm{ml} \mathrm{min}-1$. The $\mathrm{pH}$ of the mixture was recorded with a pH meter (Radiometer PHM64) and the amount of $\mathrm{CO}_{2}$ present was calculated from the volume of acid added between the two maxima of the first derivative plot of change in $\mathrm{pH}$ versus volume of acid added. Total $\mathrm{CO}_{2}$ values obtained by titration were corrected for $\mathrm{CO}_{2}$ initially present in the sodium hydroxide trap solution, which was determined in repeated 'blank' titrations. Preliminary experiments, in which ${ }^{14} \mathrm{CO}_{2}$ was added to the fuel cells as bicarbonate and was displaced into the trap by addition of acid, showed that more than $98 \%$ of $\mathrm{CO}_{2}$ was retained by the trap for quantities of $\mathrm{CO}_{2}$ similar to those measured in the experiments presented. 
Amounts of anolyte $(200 \mu \mathrm{l})$ were removed with a syringe and immediately centrifuged to separate the bacteria from the anolyte solution. Bacterial samples were washed once by resuspension in $0 \cdot 1 \mathrm{M}$-potassium phosphate, $\mathrm{pH}$ $7 \cdot 0$, and stored at $-20^{\circ} \mathrm{C}$. The stored pellets were resuspended in $100 \mu 1 \mathrm{M}-\mathrm{KOH}$ and dissolved by heating for 5 $\min$ at $100^{\circ} \mathrm{C}$, after which $10 \mu \mathrm{l}$ amounts were taken for scintillation counting; $10 \mu \mathrm{l}$ amounts of anolyte supernatants were also counted directly. The remainder of each (supernatant) sample was mixed with an equal volume of an aqueous suspension of cation-exchange resin (Dowex 50W, hydrogen form, 100-200 mesh) and shaken until all of the blue colour of the thionine had adsorbed to the resin. The resin was removed by centrifugation and the supernatant used for HPLC analysis. All samples were counted to measure loss of radioactivity by adsorption to the ion-exchange resin, which was usually insignificant.

Analysis of soluble products. HPLC analysis of anolyte supernatant samples was performed on a Varian 5000 instrument (Varian Associates, Walnut Creek, Calif, USA) with a $300 \times 6.8 \mathrm{~mm}$ Aminex Ion Exclusion HPX-87 column (Bio- $\mathrm{Rad}$ ) and $0.005 \mathrm{M}-\mathrm{H}_{2} \mathrm{SO}_{4}$ as solvent. The column was run at room temperature, and the eluate was monitored continuously at $190 \mathrm{~nm}$ by a Varian UV-80 variable wavelength detector. The eluate was collected as samples of $30 \mathrm{~s}$ duration $(0 \cdot 3 \mathrm{ml})$ into scintillation vials. Sodium $\left[{ }^{14} \mathrm{C}\right]$ acetate and sodium $\left[{ }^{14} \mathrm{C}\right]$ succinate (Amersham) standards were used to correlate times of appearance of peaks on the spectrophotometric monitor and collection of samples.

Selected pooled peak fractions eluted from the HPLC column were analysed by TLC, using precoated silica gel plates (Merck) developed with $n$-propanol/ammonia, sp. gr. $0 \cdot 88(7: 3, \mathrm{v} / \mathrm{v}$ ). Acid spots were visualized by spraying with $0.2 \%$ bromophenol blue in ethanol. Radioactive spots were visualized by autoradiography using 7-10 d exposure of Fuji X-ray RX film and eluted with two successive $0.5 \mathrm{ml}$ volumes of distilled water for scintillation counting.

Scintillation counting was performed on samples made up to $1 \mathrm{ml}$ with distilled water and mixed with $15 \mathrm{ml}$ toluene Triton X-100 $(2: 1, \mathrm{v} / \mathrm{v})$ containing $3 \cdot 33 \mathrm{~g} \mathrm{PPO}^{-1}$ and $0 \cdot 2 \mathrm{~g}$ POPOP $1^{-1}$. Samples were generally counted twice for $5 \mathrm{~min}$ at $10^{\circ} \mathrm{C}$ in a Beckman LS-233 scintillation spectrometer. Counts per min were converted to d.p.m. using an external standard channels ratio method. Efficiency of counting was between $87 \%$ and $90 \%$ for all samples.

\section{RESULTS AND DISCUSSION}

\section{Metabolism of glucose by $P$. vulgaris in a fuel cell anode compartment}

Fuel cells were fed with $10 \mu \mathrm{mol}$ or $25 \mu \mathrm{mol}$ amounts of radioactive glucose and simultaneously connected to an external resistance to allow a flow of current. The current quickly dropped to a plateau value as the ratio of reduced to oxidized mediator (thionine) decreased from the very high value established by endogenous metabolism under open circuit to the ratio resulting from the balance between mediator oxidation at the anode and re-reduction by the micro-organisms (Fig. 1). After a period of time, which depended on the amount of glucose supplied, the current fell to a low value which was similar to that obtained in fuel cells to which no substrate had been added (data not shown, but cf. Delaney et al., 1984).

The fate of glucose during this discharge of current is also shown in Fig. 1. Glucose was rapidly taken up by the micro-organisms ( $>95 \%$ in $5 \mathrm{~min}$ and $30 \mathrm{~min}$ with $10 \mu \mathrm{mol}$ and $25 \mu \mathrm{mol}$ supplied, respectively) and $40-60 \%$ of glucose radioactivity appeared simultaneously as products in the anolyte solution. Radioactive $\mathrm{CO}_{2}$ was produced more slowly, accumulating in the sodium hydroxide trap over the whole period of current flow (Fig. 1). The soluble products in the medium gave three significant peaks of radioactivity after HPLC separation. Acetate was identified as one peak, both from its retention time on HPLC, and by TLC separation. The second peak could not be certainly identified from HPLC as lactate or succinate, because these compounds were eluted close together from the HPLC column. Several samples of this peak were concentrated by freeze drying and analysed by TLC in the presence of unlabelled lactate $\left(R_{F}=0.581\right)$ and succinate $\left(R_{F}=0.238\right)$ standards. More than $80 \%$ of the radioactivity in this peak was recovered as lactate from all the samples tested and so radioactivity in this HPLC peak from all experiments was ascribed to lactate. The third peak of radioactivity eluted from the HPLC column is described as 'propionate' as it had a similar retention time to a propionate standard, but its identity was not confirmed. Standards of fumarate, 2,3-butanediol and butyrate all had retention times measurably different from this compound.

Fig. 2 shows the incorporation of radioactivity from glucose into the bacteria and the appearance of radioactive products from glucose in the anolyte of the fuel cells described in Fig. 1. Acetate was produced rapidly and was not significantly reincorporated. Significant amounts 

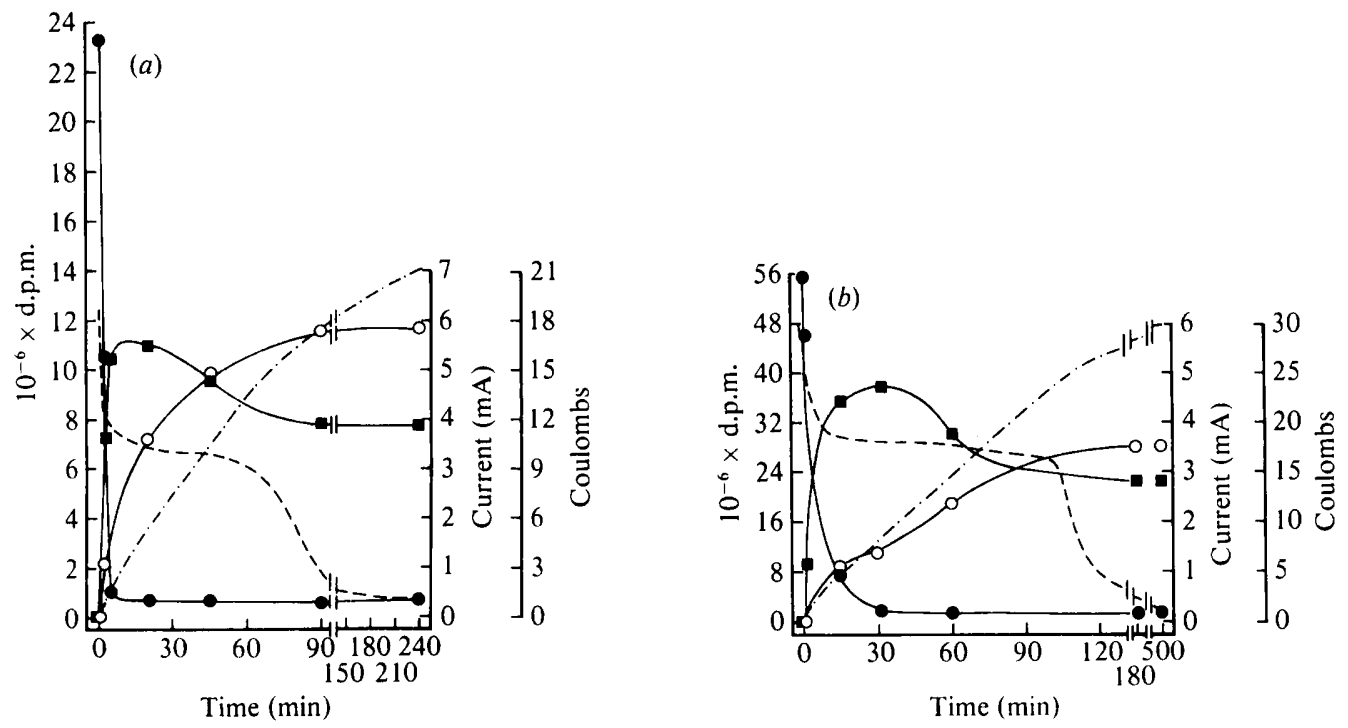

Fig. 1. Fuel cell performance. Current (---) and coulombs delivered (-..-) by thionine-mediated $P$. tulgaris fuel cells following addition of $\left[\mathrm{U}^{-1+} \mathrm{C}\right]$ glucose $(a, 10 \mu \mathrm{mol} ; b, 25 \mu \mathrm{mol})$ and with $100 \Omega$ external load resistance. Disappearance of $\left[{ }^{1+} \mathrm{C}\right] \mathrm{glucose}$ from the anolyte $(O)$ and production of soluble radioactive products $(\square)$ were measured in samples withdrawn from the anode compartment. ${ }^{1+} \mathrm{CO}_{2}(\mathrm{O})$ was measured by subtraction of radioactivity found in glucose, in soluble products and incorporated in the bacteria (see Fig. 2) from the initial radioactivity in the glucose supplied. Specific activity of glucose was $2.22 \times 10^{6}$ d.p.m. $\mu \mathrm{mol}^{-1}\left(37 \mathrm{GBq} \mathrm{mol}^{-1}\right)$. Note that the abscissa scales are not continuous.
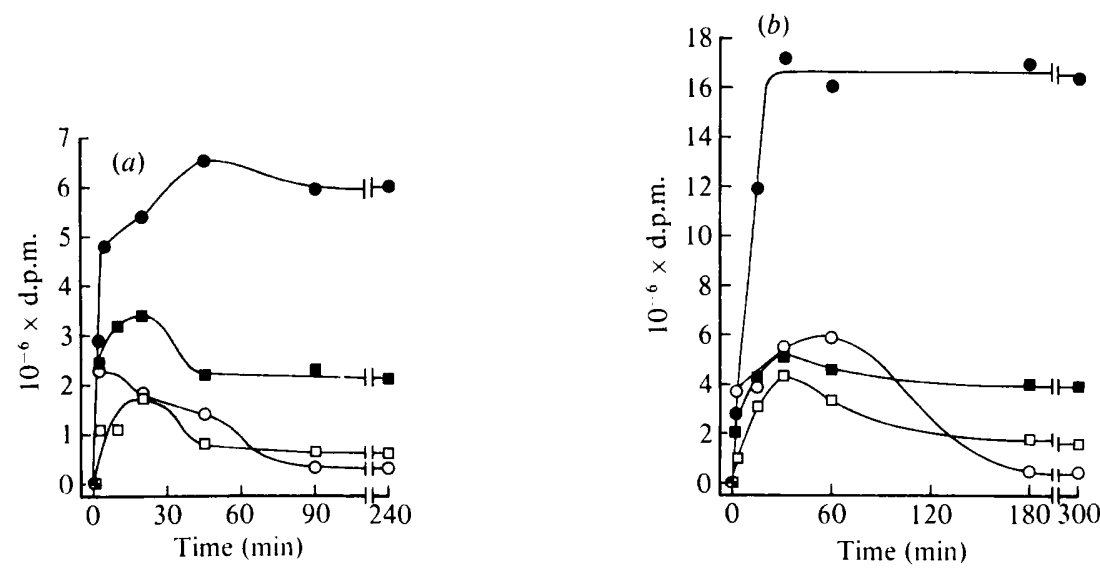

Fig. 2. Products of glucose metabolism in the thionine-mediated $P$. tulgaris fuel cell. Samples withdrawn from the anode compartments of fuel cells described in the legend to Fig. 1 were analysed for incorporation of $\left[\mathrm{U}^{-1+} \mathrm{C}\right] \mathrm{glucose}$ into bacteria $(\boldsymbol{\square})$ and for accumulation of ${ }^{1+} \mathrm{C}$ in acetate $(\boldsymbol{O})$, lactate (O) and 'propionate' $(\square)$ in the anolyte. Data in $(a)$ are for a fuel cell supplied with $10 \mu \mathrm{mol}$ $\left[{ }^{1+} \mathrm{C}\right]$ glucose and those in $(b)$ for one supplied with $25 \mu \mathrm{mol}\left[{ }^{1+} \mathrm{C}\right]$ glucose. Details of the analyses are given in Methods. Note the break in the abscissa scales.

of lactate, and to a lesser extent 'propionate', were found in the anolyte, but both were subsequently reincorporated to a large extent. The experiments were continued until there was no significant change in measured quantities, when the distribution of radioactivity was as follows: $5-10 \%$ was incorporated in the organisms, $25-30 \%$ was in acetate, about $10 \%$ was distributed in other soluble products in the anolyte solution (not more than $3 \%$ in any one compound, and insufficient for precise individual measurement), and $40-50 \%$ was trapped as 
${ }^{14} \mathrm{CO}_{2}$. Typically, $94-98 \%$ of added radioactivity was recovered. Therefore, when glucose was added to a fuel cell which was allowed to discharge producing a sustained current, it was metabolized extremely rapidly, producing transient accumulation of lactate and 'propionate', but ultimately being incorporated into the bacteria, or converted to $\mathrm{CO}_{2}$ and acetate (and electricity!).

Although the recovery of radioactivity at the end of each experiment was good, as stated above, this was not so for samples taken during the time course of each experiment, if radioactivity in $\mathrm{CO}_{2}$ was determined in samples removed from the sodium hydroxide trap. We showed in preliminary experiments that $\left[{ }^{14} \mathrm{C}\right]$ bicarbonate added to $0 \cdot 1 \mathrm{M}$-potassium phosphate buffer in the fuel cell apparatus was transferred quantitatively and rapidly into the sodium hydroxide trap, but this was not so in complete fuel cell experiments. We were unable to increase the rate of $\mathrm{CO}_{2}$ transfer by incorporation of carbonic anhydrase $\left(500 \mu \mathrm{g} \mathrm{ml}^{-1}\right)$ in the anolyte fluid, but a significant increase in rate of accumulation of $\mathrm{CO}_{2}$ in the trap occurred if the anolyte was made acid ( $\mathrm{pH} \mathrm{1.8-3.4)} 30 \mathrm{~min}$ after the start of an experiment, although this immediately stopped metabolic activity. Incomplete recovery of radioactivity during fuel cell runs was therefore investigated. Control experiments showed that less than $1 \%$ of total radioactivity was transferred through the ion-exchange membrane into the catholyte. By recombining the buffer used for washing samples of bacteria with the anolyte supernatant from which they had been separated, it was shown that no significant quantity of radioactivity washed out of bacterial samples. Most significantly, $\left[{ }^{14} \mathrm{C}\right]$ formate and $\left[{ }^{14} \mathrm{C}\right]$ acetate were adsorbed from solution in blank fuel cells containing buffer and mediator but no micro-organisms. Both compounds were adsorbed strongly to the carbon electrode, but also to the ion-exchange membrane. When $10 \mu \mathrm{mol}\left[{ }^{14} \mathrm{C}\right]$ formate or $\left[{ }^{14} \mathrm{C}\right]$ acetate was added to anode compartments without bacteria, $40 \%$ and $25 \%$, respectively, were adsorbed within $15 \mathrm{~min}$ and retained for a further $100 \mathrm{~min}$. This adsorption phenomenon was much less marked in the absence of thionine, with electrode material and ion-exchange membrane which had never been exposed to thionine. Thionine binds strongly to both these materials. We conclude that in fuel cell experiments where recovery of radioactivity was essentially complete, incomplete recovery of radioactivity in earlier time samples was most probably due to transient adsorption of $\left[{ }^{14} \mathrm{C}\right]$ formate and/or $\left[{ }^{14} \mathrm{C}\right]$ acetate which was ultimately metabolized to ${ }^{1+} \mathrm{CO}_{2}$. Consequently we have calculated radioactivity in $\mathrm{CO}_{2}$ both from samples of sodium hydroxide trap solution and by difference between initial added glucose radioactivity and radioactivity found in the anolyte solution plus radioactivity in the washed organism pellets. In Fig. 1 we show ${ }^{14} \mathrm{CO}_{2}$ evolution calculated by difference. The pattern of accumulation of ${ }^{14} \mathrm{CO}_{2}$ in the trap differed in that it showed a lag. For instance, in the experiment shown in Fig. $1\left(\right.$ a), the midpoint of the increase in trapped ${ }^{14} \mathrm{CO}_{2}$ was delayed by 30 min when compared with the curve shown, although the amount of ${ }^{14} \mathrm{CO}_{2}$ obtained after 240 min was the same by both methods of determination in this particular experiment.

\section{Coulombic yield from glucose}

Table 1 shows a summary of data for $\mathrm{CO}_{2}$ evolved and coulombs obtained in sume representative experiments where current was drawn at a fixed resistive load after addition of a known amount of glucose. The estimate of $\mathrm{CO}_{2}$ derived from glucose, obtained by correcting the chemically measured amount of $\mathrm{CO}_{2}$ evolved for endogenous activity, is in general agreement with the data for radioactive $\mathrm{CO}_{2}$ collected. The addition of glucose to the system did not therefore measurably affect the (rate of) transfer of electrons dependent on oxidation of endogenous material of the organisms. It may be that addition of an exogenous oxidizable substrate can alter the extent to which endogenous material is oxidized to yield electric current under different conditions from those we used here, such as with much larger or smaller additions of glucose, or where very different resistive loads are applied, or indeed where different organisms are used.

The yield of coulombs generally correlated with the yield of $\mathrm{CO}_{2}$, in that although the ratio of coulombs to $\mathrm{CO}_{2}$ varied from one experiment to another, the mean ratio was close to the expected value for oxidation from the level of carbohydrate to $\mathrm{CO}_{2}$, and this was true both for total yields and for those attributed to glucose by subtraction of endogenous values (Table 1). 


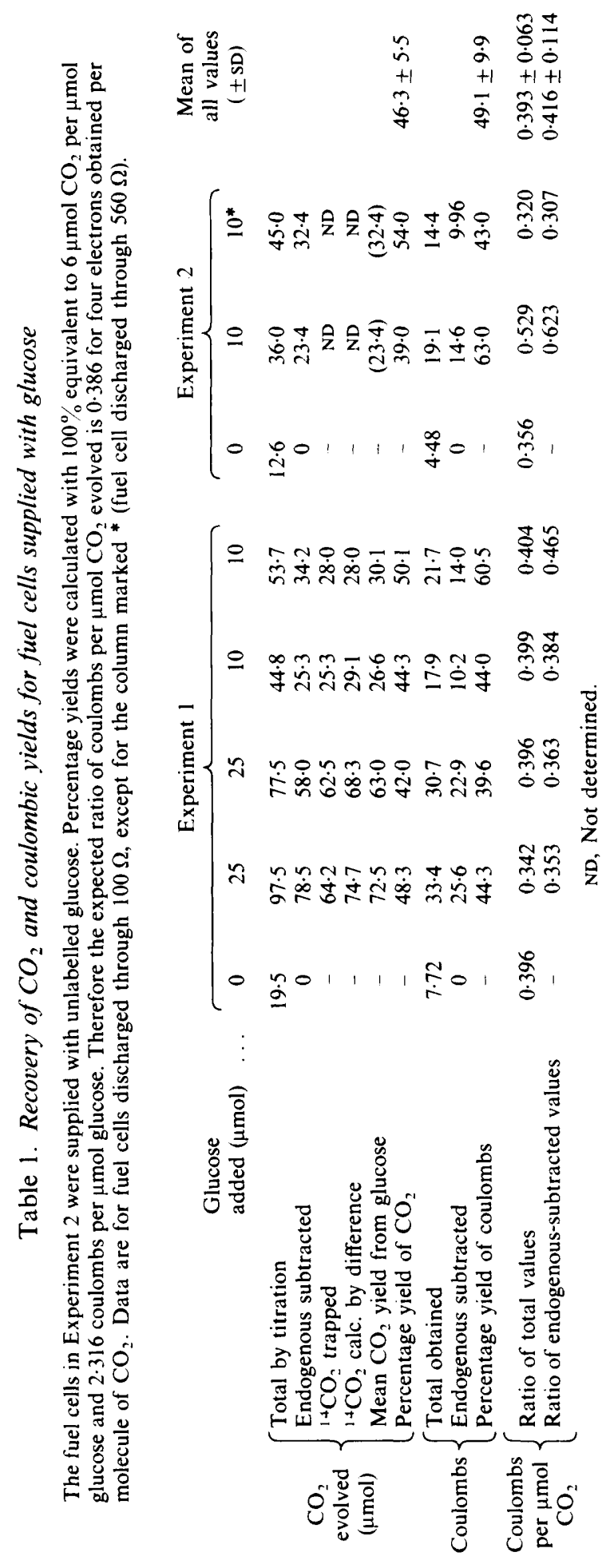




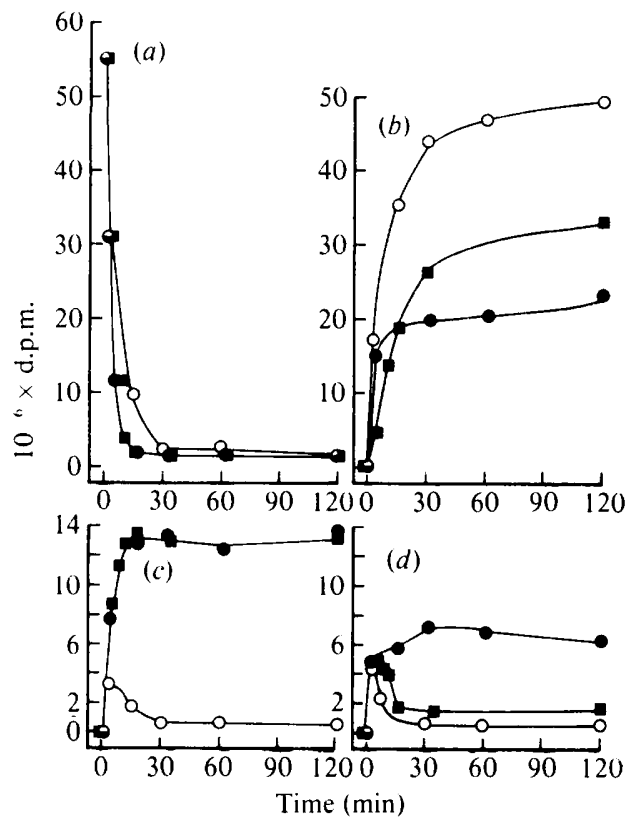

Fig. 3. Comparison of glucose metabolism in the fuel cell with conventional aerobic and anaerobic conditions. [U-1 $\left.{ }^{14} \mathrm{C}\right] \mathrm{Glucose}\left(10 \mu \mathrm{mol} ; 5.49 \times 10^{6} \mathrm{~d}\right.$.p.m. $\left.\mu \mathrm{mol}^{-1}, 91.5 \mathrm{GBq} \mathrm{mol}^{-1}\right)$ was supplied to each of the three fuel cell anode compartments at zero time. One fuel cell was discharged through $100 \Omega$ resistance and was similar to that for which data are shown in Figs $1(a)$ and $2(a)(0)$. The second fuel cell was left under open circuit $(\mathcal{O})$ and the third was both left under open circuit and bubbled with air in place of nitrogen $(O)$. The cells were sampled for $(a)\left[{ }^{14} \mathrm{C}\right]$ glucose in the anolyte, and for production of $(b){ }^{14} \mathrm{CO}_{2},(c)\left[{ }^{14} \mathrm{C}\right]$ acetate and $(d)\left[{ }^{14} \mathrm{C}\right]$ lactate. Details of the analyses are given in Methods.

Thus the recovery of electrons from the process of oxidation of glucose to $\mathrm{CO}_{2}$ was without measurable loss and was about half of the electrons available from glucose because only half of the glucose was oxidized to $\mathrm{CO}_{2}$. As the overall oxidation state of acetate is the same as that of glucose, we infer that the average oxidation state was similar for the $20 \%$ of glucose-derived material remaining in the organisms, or as products other than acetate in the anolyte.

\section{Effect of anode compartment conditions on glucose metabolism by P. vulgaris}

The conditions imposed on the organisms in a fuel cell anode compartment were intermediate between normal aerobic and anaerobic conditions. Although no oxygen was present, electrons withdrawn from the organisms via the mediator were not available for the reduction of metabolic intermediates as normally occurs in anaerobic fermentation. Fuel cell conditions were compared to normal aerobic and anaerobic conditions by monitoring glucose metabolism in the fuel cell apparatus when no current was drawn (under open circuit) with air or nitrogen as the gas supplied, and in the presence or absence of thionine. In the presence of oxygen results were the same, with and without thionine (Table 2). Under anaerobic conditions there was relatively less 'propionate' and more acetate formed when thionine was present, but in general the addition of mediator did not change the pattern of glucose metabolism when no electric current was allowed to flow.

In contrast, the presence of oxygen, drawing current in the fuel cell, and open circuit anaerobic conditions each produced a characteristically different pattern of glucose metabolism (Fig. 3 and Table 2). The presence of oxygen resulted in a decrease in the rate of glucose uptake compared with 'fuel cell' and anaerobic conditions. Under anaerobic conditions less $\mathrm{CO}_{2}$ was produced and the fermentation products acetate, lactate and 'propionate' accumulated and were not substantially reincorporated (data for 'propionate' not shown). 


\title{
Table 2. Recovery of products from $\left[{ }^{14} \mathrm{C}\right] \mathrm{glucose}$ added to the fuel cell apparatus under different conditions
}

\begin{abstract}
Fuel cell anode compartments were supplied with $10 \mu \mathrm{mol}\left[\mathrm{U}-{ }^{1+} \mathrm{C}\right]$ glucose as described in the legend to Fig. 3. Residual glucose and products of glucose metabolism were analysed after $4 \mathrm{~h}$ incubation. Data under the heading 'Fuel cell' are for a fuel cell discharged through $100 \Omega$ external resistance as shown in Fig. $1(a)$ and Fig. 3. Data under the heading 'Anaerobic' are for fuel cells under open circuit with and without thionine in the anolyte. Data under the heading 'Aerobic' are for fuel cells under open circuit which had air, rather than nitrogen, bubbled through the anode compartment, also with and without thionine in the anolyte. Data for 'Anaerobic' and 'Aerobic' conditions with thionine present are shown in Fig. 3.
\end{abstract}

\begin{tabular}{|c|c|c|c|c|c|}
\hline \multirow{3}{*}{$\begin{array}{l}\text { Gas } \\
\text { supplied } \ldots \\
\text { Thionine } \\
\text { present } \ldots\end{array}$} & \multicolumn{5}{|c|}{$\begin{array}{c}\text { Percentage of initial } \\
{\left[{ }^{1+} \mathrm{C}\right] \text { glucose radioactivity recovered after } 4 \mathrm{~h}}\end{array}$} \\
\hline & \multicolumn{2}{|c|}{$\begin{array}{c}\text { 'Aerobic' } \\
\text { Air }\end{array}$} & \multirow{2}{*}{$\begin{array}{c}\text { 'Fuel cell' } \\
\text { Nitrogen } \\
\text { Yes }\end{array}$} & \multicolumn{2}{|c|}{$\begin{array}{c}\text { 'Anaerobic' } \\
\text { Nitrogen }\end{array}$} \\
\hline & No & Yes & & No & Yes \\
\hline Glucose & $2 \cdot 7$ & $3 \cdot 5$ & $3 \cdot 1$ & $2 \cdot 7$ & $2 \cdot$ \\
\hline $\mathrm{CO}_{2}$ & $66 \cdot 3$ & $64 \cdot 7$ & $46 \cdot 5$ & $19 \cdot 5$ & $19 \cdot 2$ \\
\hline Acetate & $1 \cdot 3$ & $1 \cdot 1$ & $27 \cdot 0$ & $20 \cdot 9$ & $25 \cdot 5$ \\
\hline Lactate & $1 \cdot 3$ & $1 \cdot 1$ & $1 \cdot 3$ & $7 \cdot 7$ & $11 \cdot 5$ \\
\hline Propionate' & $0 \cdot 2$ & 0.2 & $2 \cdot 7$ & $9 \cdot 1$ & $3 \cdot 1$ \\
\hline Bacteria & $9 \cdot 0$ & $2 \cdot 8$ & $9 \cdot 5$ & $8 \cdot 8$ & $6 \cdot 8$ \\
\hline Total recovered & $83 \cdot 7$ & $73 \cdot 8$ & 93.9 & $82 \cdot 5$ & $77 \cdot 7$ \\
\hline
\end{tabular}

It is of particular note that when current was drawn in the fuel cell only transient accumulation of lactate and 'propionate' occurred, as during aerobic glucose metabolism. But glucose was more rapidly taken up, and excreted acetate was not reincorporated and oxidized to $\mathrm{CO}_{2}$, which was similar to the pattern of anaerobic glucose metabolism.

Although these data illustrate well that glucose metabolism in the fuel cell under load is intermediate between conventional aerobic and anaerobic metabolism, recovery of radioactivity was incomplete under 'non-fuel-cell' conditions. If this was due to adsorption of ${ }^{14} \mathrm{C}$-labelled compounds to electrodes, as described above, there may have been significant accumulation of compounds such as formate which were not detected by HPLC analysis.

\section{CONCLUSIONS}

In the experiments described, fuel cells were operated as batteries in that a single addition of fuel was completely consumed, in order to study the quantitative relationship between glucose oxidation and production of electricity. Such systems can, however, be operated as regenerative batteries with repeated addition of fuel (Stirling et al., 1983; Delaney et al., 1984), and as true fuel cells with continuous fuel supply (Roller et al., 1983). The current drawn was equivalent to 0.1 A per $\mathrm{g}$ of organisms, i.e. $3 \mathrm{~mA}$ from $30 \mathrm{mg}$ of $P$. vulgaris in the experiments described, and preliminary experiments in larger fuel cells show that the relationship between current and amount of organisms holds with $2-300 \mathrm{mg}$ of $P$. vulgaris. Although $0.1 \mathrm{~A}$ per $\mathrm{g}$ of organisms is probably sufficient for practicable operation of a battery device, we have calculated elsewhere that the maximum activity of this type of system could be substantially greater, of the order of 1 A per $\mathrm{g}$ of organisms (Stirling et al., 1983).

The coulombic yield for glucose of about $50 \%$ is already sufficient from the point of view of practical application, but any increase obtained would also clearly be desirable. Energetic yields from microbial fuel cells will be discussed elsewhere. The incorporation of glucose into cellular material (Table 2) may result in loss of electricity which could be recovered. It might be possible to inhibit the reactions leading to substrate assimilation, or since endogenous metabolism can yield electrons in apparently the same way as from exogenous fuel (Table 1), the scavenging of this extra yield might occur without modifying the system in extended fuel cell operation. The 
single most significant loss resulted from the conversion of about a third of the glucose to acetate which was not further metabolized. If this could be avoided, the coulombic yield would be at least $70 \%$. The accumulation of acetate during glucose metabolism has been thoroughly investigated in Escherichia coli (Britten, 1954; Holms \& Bennett, 1971) and may be a common phenomenon for enteric bacteria, but it may also be that other types of micro-organisms might be used which do not behave in this way. More directly, the accumulation of acetate may possibly be prevented by modification of $P$. vulgaris or by changes in the mode of operation of the fuel cell. To this end it would be most desirable to know whether both the lower rate of glucose uptake and the more complete oxidation of accumulated acetate seen under aerobic conditions are strictly dependent on the availability of oxygen (Fig. 3). It may only be that aerobic conditions allow some metabolic reactions to run at higher rates than allowed in the fuel cell.

The clear conclusion to be drawn is that electron transfer via redox mediators is highly efficient, and that the efficiency of the overall system, whilst good, may be further improved through a better understanding of the biological components.

We gratefully acknowledge support from the SERC and the loan of electrode materials from Johnson Matthey Research Ltd.

\section{REFERENCES}

Aston, W. J. \& Turner, A. P. F. (1984). Biosensors and biofuel cells. In Biotechnology and Genetic Engineering Reviews 1, pp. 89-120. Edited by G. E. Russel. Newcastle upon Tyne: Intercept.

BenetTo, H. P. (1984). Microbial fuel cells. Life Chemistry Reports 2, 363-453.

Bennetto, H. P., Stirling, J. L., Tanaka, K. \& Vega, C. A. (1983). Anodic reactions in microbial fuel cells. Biotechnology and Bioengineering 25, 559-568.

BRITTEN, R. J. (1954). Extracellular metabolic products of Escherichia coli during rapid growth. Science 119, 578.

Davis, G., Hill, H. A. O., Aston, W. J., Higgins, I. J. \& TURNER, A. P. F. (1983). Bioelectrochemical fuel cell and sensor based on a quinoprotein, alcohol dehydrogenase. Enzyme and Microbial Technology 5 , 383-388.

Delaney, G. M., Bennetto, H. P., Mason, J. R., Roller, S. D., Stirling, J. L. \& Thurston, C. F. (1984). Electron-transfer coupling in microbial fuel cells. 2. Performance of fuel cells containing selected microorganism-mediator-substrate combinations. Journal of Chemical Technology and Biotechnology 34B, 13-27.

Holms, W. H. \& BENNETT, P. M. (1971). Regulation of isocitrate dehydrogenase activity in Escherichia coli on adaptation to acetate. Journal of General Microbiology 65, 57-68.

Roller, S. D., Bennetto, H. P., Delaney, G. M., Mason, J. R., Stirling, J. L., Thurston, C. F. \& WhITE, D. R. (1983). A bio-fuel cell for utilisation of lactose wastes. In Proceedings of the First World Conference on the Commercial Applications of Biotechnology (BIOTECH 83), pp. 655-663. London: Online Publications Ltd.

Stirling, J. L., Bennetto, H. P., Delaney, G. M., Mason, J. R., Roller, S. D., Tanaka, K. \& Thurston, C. F. (1983). Microbial fuel cells. Biochemical Society Transactions 11, 451-453. 